\title{
Europejska Sieć Ekologiczna Natura 2000 a zrównoważony rozwój obszarów wiejskich
}

Europejska Sieć Ekologiczna Natura 2000 powiązana jest ściśle z ideą zrównoważonego rozwoju. Co prawda, polski ustawodawca w ustawie z dnia 16 kwietnia 2004 r. o ochronie przyrody ${ }^{2}$ wskazuje jedynie na definicję integralności obszaru Natura 2000 jako spójności czynników strukturalnych i funkcjonalnych warunkujących zrównoważone trwanie populacji gatunków i siedlisk przyrodniczych, dla ochrony których zaprojektowano lub wyznaczono obszar Natura 2000, ale wykładnia systemowa prawa pozwala dostrzec koegzystowanie Natury 2000 oraz zrównoważonego rozwoju obszarów wiejskich. ${ }^{3}$ Zrównoważone trwanie populacji i gatunków siedlisk przyrodniczych określone w ustawie o ochronie przyrody jest częścią idei zrównoważonego rozwoju. To wspólistnienie przejawia się na wszystkich poziomach legislacji związanej z Naturą 2000, zarówno w planach ochronnych, wprowadzanych rozporządzeniem Ministra Środowiska, jak też w planach zadań ochronnych, obowiązujących na podstawie zarządzenia regionalnego dyrektora ochrony środowiska. ${ }^{4}$

Podstawowym problemem prawnym jest znalezienie odpowiedzi na pytanie, czy zrównoważony rozwój obszarów wiejskich jest właściwie rozumiany i stosowany z wykorzystaniem formy ochrony przyrody, jaką jest Natura $2000 .{ }^{5}$ Tak postawione pytanie wskazuje na istniejące $\mathrm{w}$ tym zakresie problemy sprowadzające się do

$1 \quad$ Uniwersytet w Białymstoku, Uniwersytet Warszawski

2 Badania zostały sfinansowane ze środków Narodowego Centrum Nauki przyznanych w ramach finansowania stażu po uzyskaniu stopnia naukowego doktora na podstawie decyzji numer DEC-2012/04/S/HS5/00338. Tekst jednolity Dz.U. z 2009 r. Nr 151, poz. 1220 z późn. zm.

3 A. Bołtromiuk (red.), Europejska Sieć Ekologiczna Natura 2000 jako nowy element otoczenia polskiej wsi i rolnictwa, Warszawa 2010; A. Bołtromiuk, M. Kłodziński (red.), Natura 2000 jako czynnik zrównoważonego rozwoju obszarów wiejskich regionu Zielonych Płuc Polski, Warszawa 2011.

$4 \quad$ EC COM 431 final: Communication from the Commission to the Council and the European Parliament: Financing Natura 2000, 2004; J. Engel, Natura 2000 w ocenach oddziaływania przedsięwzięć na środowisko, Warszawa 2010; S. Gantioler, P. Brink, S. Bassi, M. Kettunen, A. McConville, M. Rayment, Financing Natura 2000 - Financing needs and socio-economic benefits resulting from investment in the network, 2010; Natura 2000: szanse i zagrożenia, Warszawa 2010.

5 P. Czechowski, A. Niewiadomski, Natura 2000 a parki narodowe - wybrane problemy prawne, [w:] Administracja publiczna a ochrona przyrody. Zagadnienia ekonomiczne, społeczne oraz prawne, M. Górski, D. Niedziółka, R. Stec, D. Strus (red.), Warszawa 2012, s. 101-116. 
rozstrzygnięcia sporu pomiędzy prawem prywatnym a publicznym. Problemem jest również sama definicja zrównoważonego rozwoju. Jak się podkreśla, szczyt Rio+20 dopracował się 436 definicji tego pojęcia. W tym chaosie znaczeń i kolejnych deklaracji co do idei zrównoważonego rozwoju z punktu widzenia prawnego nie wypracowano jego jednolitej definicji legalnej. Konieczność współpracy sektora publicznego i prywatnego została podkreślona w dokumencie końcowym szczytu Rio+20. Wskazano także na konieczność wprowadzenia regulacji prawnych, promujących odpowiedzialny biznes. Te wszystkie elementy nowej projektowanej definicji zrównoważonego rozwoju będą musiały zostać uwzględnione w procesie stosowania polskiego prawa ochrony przyrody, w szczególności w zakresie sieci Natura 2000. ${ }^{6}$

Pogodzenie idei ochrony środowiska, realizowanej także w ramach Natura 2000 i zrównoważonego rozwoju, który wspiera odpowiedzialny biznes będzie wymagało stworzenia nowego prawa o charakterze publiczno-prywatnym. W pierwszej kolejności, uwzględniając wskazania szczytu, należy dbać o ochronę środowiska, jednocześnie mając na względzie dobro podmiotów gospodarczych, które chcą realizować swoje zamierzenia inwestycyjne w zgodzie z przyrodą. Znalezienie wspólnych rozwiązań może okazać się kluczem do realizacji idei zrównoważonego rozwoju. Ustawodawca stanie przed wyborem realizacji dwóch zadań: ochrony środowiska naturalnego i obszarów cennych przyrodniczo oraz stworzenia ram prawnych do prowadzenia działalności gospodarczej na tych obszarach i w ich otoczeniu.

Należy wskazać, że jednym z głównych osiągnięć Rio+20 jest decyzja o ustanowieniu celów zrównoważonego rozwoju, które za trzy lata weszłyby na miejsce milenijnych celów rozwoju przyjętych na Zgromadzeniu Ogólnym ONZ w 2000 r. oku. Niestety, nie zdefiniowano wprost celów zrównoważonego rozwoju, wskazując jedynie na ich ekonomiczne, społeczne i środowiskowe podstawy. W tym ostatnim zakresie końcowe porozumienie mówi o zielonej gospodarce jako o instrumencie, który można wykorzystywać wedle indywidualnych potrzeb, w zależności od realiów poszczególnych krajów. Może ona stanowić zestaw możliwych do wykorzystania opcji, ale nie powinna być sztywnym, uniwersalnym zbiorem zasad. Z końcowego raportu konferencji wynika, że do 2015 r. zdefiniowane oraz ogłoszone powinny zostać cele zrównoważonego rozwoju. W dokumencie końcowym zatytułowanym „Przyszłość, której chcemy” zrównoważony rozwój opisywany jest jako rozwój gospodarczy, który jednocześnie poprawia standardy życia przy poszanowaniu środowiska naturalnego.

W prawie polskim zasada zrównoważonego rozwoju została wyrażona w art. 5 Konstytucji RP. Jej rozwinięcie znajduje się jednak w innych aktach prawnych. Lean, Ochrona środowiska w działalności gospodarczej, Warszawa 2003; J. Ciechanowicz-McLean, Z. Bukowski, B. Rakoczy, Prawo ochrony środowiska: komentarz, Warszawa 2008. 
Podstawową definicję dla polskiego prawa w zakresie zrównoważonego rozwoju ${ }^{7}$ zawarto w Prawie ochrony środowiska, gdzie w art. 3 pkt 50 możemy przeczytać, iż „zrównoważony rozwój, to taki rozwój społeczno-gospodarczy, w którym następuje proces integrowania działań politycznych, gospodarczych i społecznych, z zachowaniem równowagi przyrodniczej oraz trwałości podstawowych procesów przyrodniczych, w celu zagwarantowania możliwości zaspokajania podstawowych potrzeb poszczególnych społeczności lub obywateli zarówno współczesnego pokolenia, jak i przyszłych pokoleń". ${ }^{8}$ Ta definicja znajduje także zastosowanie do regulacji prawnych odnoszących się do obszarów Natura 2000 w Polsce. Budzi ona jednak liczne kontrowersje nie tylko u praktyków i w nauce, ale także w orzecznictwie. ${ }^{9}$

W takich ramach organizacyjnych zrównoważonego rozwoju, a w szczególności w jego środowiskowym filarze działa Europejska Sieć Natura 2000. Objęte są nią kraje Unii Europejskiej. Zajmuje ona obecnie 1/6 powierzchni lądowej krajów Unii Europejskiej. Sieć obszarów Natura 2000 jest w swych podstawowych założeniach regulowana dwutorowo. W regulacjach prawa europejskiego dwoma dyrektywami: dyrektywą Rady 79/409/EWG z dnia 2 kwietnia 1979 r. w sprawie ochrony dzikich ptaków ${ }^{10}$ oraz dyrektywą Rady 94/43/EWG z dnia 21 maja 1992 r. w sprawie ochrony siedlisk naturalnych oraz dzikiej fauny i flory. ${ }^{11} \mathrm{~W}$ prawie polskim problematyka sieci Natura 2000 regulowana jest wspomnianą już ustawą z dnia 16 kwietnia 2004 r. o ochronie przyrody. Natura 2000 w Polsce obejmuje swym zasięgiem ok. 6,2 mln ha. ${ }^{12}$

W Polsce w praktyce zrównoważony rozwój obszarów wiejskich realizowany jest przede wszystkim w ramach programów rolnośrodowiskowych w Programie Rozwoju Obszarów Wiejskich na lata 2007-2013. ${ }^{13}$ Programy rolnośrodowiskowe mają przede wszystkim na celu poprawę środowiska przyrodniczego i obszarów wiejskich. Podejmowane są inicjatywy w zakresie przywracania walorów lub utrzymania stanu cennych siedlisk użytkowanych rolniczo oraz zachowanie różnorodności biologicznej na obszarach wiejskich; promowania zrównoważonego systemu gospodarowania; odpowiednie użytkowanie gleb i ochrona wód; ochrona zagrożonych lokalnych ras zwierząt gospodarskich i lokalnych odmian roślin uprawnych. ${ }^{14}$

Z. Bukowski, Zrównoważony rozwój w systemie prawa, Toruń 2009; Uwarunkowania ochrony środowiska: aspekty krajowe, unijne, międzynarodowe, E. Czech (red.), Warszawa 2006; E. Czech, Szkoda w obszarze środowiska i wina jako determinanty odpowiedzialności administracyjnej za szkodę, Białystok 2008.

8

Ustawa z dnia 27 kwietnia 2001 r. Prawo ochrony środowiska (Dz.U. z 2008 r. Nr 25, poz. 150 z późn. zm.).

Por. Wyrok NSA z 26 października 2011 r. (II OSK 1820/11); Wyrok WSA w Warszawie z dnia 23 czerwca 2009 r. (IV SA/Wa 1269/08); Wyrok WSA w Gorzowie Wielkopolskim z dnia 25 marca 2009 r. (II SA/Go 825/08); Wyrok NSA z dnia 7 lipca 2006 r. (II OSK 507/06).

Dz. U. UE L z 1979 r. Nr 103, s. 1 z późn. zm. - zwaną „dyrektywą ptasią”.

Dz. U. UE L z 1992 r. Nr 206, s. 7 z późn. zm. - zwaną „dyrektywą siedliskową”.

Źródło danych - Generalna Dyrekcja Ochrony Środowiska.

M.P. z 2007 r. Nr 94, poz. 1035 z późn. zm.

Zarys tej problematyki przedstawiłem już wstępnie w P. Czechowski, A. Niewiadomski, Natura 2000 a parki narodowe - wybrane problemy prawne, [w:] Administracja publiczna a ochrona przyrody. Zagadnienia ekonomiczne, 
Działania objęte programami rolnośrodowiskowymi obejmują Pakiet 4. Ochrona zagrożonych gatunków ptaków i siedlisk przyrodniczych poza obszarami Natura 2000 oraz Pakiet 5. Ochrona zagrożonych gatunków ptaków i siedlisk przyrodniczych na obszarach Natura 2000. Uregulowana w rozporządzeniu Ministra Rolnictwa i Rozwoju Wsi z dnia 26 lutego 2009 r. w sprawie szczegółowych warunków i trybu przyznawania pomocy finansowej w ramach działania „Program rolnośrodowiskowy" objętego PROW na lata $2007-2013^{15}$ procedura ubiegania się o pomoc z tego działania, wymienia jako jeden z pakietów, w ramach którego realizowane są zobowiązania rolnośrodowiskowe Pakiet 5. Opisane w rozporządzeniu wymagania w pewnych częściach powtarzają elementy planów zadań ochronnych, które są podstawowym instrumentem prawnym realizacji zadań określonych dla Natury 2000. Wymagania te, które są dość kosztochłonne dla potencjalnego beneficjenta, mogą ograniczyć możliwości ubiegania się o pomoc. Istniejąca obecnie dwoistość regulacji w tym zakresie wymaga powstania uzupełniającego się reżimu prawnego. $\mathrm{Z}$ jednej strony to prawo publiczne w postaci ustawy o ochronie przyrody i zawartych w niej regulacji związanych z planem zadań ochronnych. Ten akt prawa miejscowego rozstrzyga faktycznie o wymaganiach wobec właścicieli nieruchomości nim objętych. $Z$ drugiej strony to obowiązki nakładane w drodze umów cywilnoprawnych na beneficjentów działań rolnośrodowiskowych w postaci zobowiązań rolnośrodowiskowych. Plan zadań ochronnych (PZO), przygotowywany w skomplikowanej procedurze powinien być efektywniej wykorzystywany. ${ }^{16}$ Plan zadań ochronnych sporządzany jest na 10 lat i jest obowiązkowy dla każdego obszaru Natura 2000 (z wyjątkiem obszarów morskich, obszarów lub ich części, dla których sporządzono plan ochrony lub obszarów pokrywających się (1) w całości lub w części z obszarem parku narodowego, ${ }^{17}$ rezerwatu przyrody lub parku krajobrazowego, dla których ustanowiono plan ochrony z zakresem PZO, (2) z obszarem parku narodowego ${ }^{18}$ lub rezerwatu przyrody, dla których ustanowiono zadania ochronne z za-

społeczne oraz prawne, M. Górski, D. Niedziółka, R. Stec, D. Strus (red.), Warszawa 2012, s. 101-116 - w niniejszym artykule zawarto rozwinięcie i uzupełnienie tej problematyki.

Dz.U. z 2009 r. Nr 33, poz. 262 z późn. zm.

Z. Bukowski, Udział społeczeństwa w ochronie przyrody, [w:] Administracja publiczna a ochrona przyrody. Zagadnienia ekonomiczne, społeczne oraz prawne, M. Górski, D. Niedziółka, R. Stec, D. Strus (red.), Warszawa 2012, s. 11-22; R. Wojciechowski, Społeczno-polityczne i ekonomiczne aspekty realizacji polityki ekologicznej, [w:] Administracja publiczna a ochrona przyrody. Zagadnienia ekonomiczne, społeczne oraz prawne, M. Górski, D. Niedziółka, R. Stec, D. Strus (red.), Warszawa 2012, s. 87-98.

17 A. Wodziczko, Na straży przyrody. Wiadomości i wskazania z dziedziny ochrony przyrody, Kraków 1948; W. Szafer, Ochrona przyrodniczego środowiska człowieka, Warszawa 1976; M. Górski, Opinia prawna dotycząca projektu ustawy o ochronie przyrody, Łódź, 29 września 2003 r.; Prawo ochrony przyrody. Komentarz, J. Sommer (red.), Wrocław 2001; R. Paczuski, Prawo ochrony środowiska, Bydgoszcz 2000; K. Gruszecki, Prawo ochrony środowiska. Komentarz, Warszawa 2008; J. Jerzmański, Opinia prawna w sprawie ustawy o ochronie przyrody (druk 1982), Wrocław, 29 września 2003 r.; R. Paczuski, Opinia do projektu ustawy o ochronie przyrody (druk 1982), Bydgoszcz 2003; P. Bojarski, Rekompensata za ograniczenia związane z ochroną przyrody, [w:] Teoretyczne podstawy ochrony przyrody, W. Radecki (red.), Wrocław 2006; W. Bołdok, Kilka uwag dotyczących obrotu nieruchomościami położonymi w rejonie parku narodowego, „Nowy Przegląd Notarialny” 2004, nr 3; K. Gruszecki, Następstwa prawne wyznaczenia otuliny parków narodowych oraz rezerwatów przyrody, „Casus” 2006, nr 1. J. Ciechanowicz-McLean, Parki Narodowe w prawnym systemie ochrony przyrody, [w:] Administracja publiczna a ochrona przyrody. Zagadnienia ekonomiczne, społeczne oraz prawne, M. Górski, D. Niedziółka, R. Stec, 
kresem PZO, (3) z obszarem będącym w zarządzie nadleśnictwa, dla którego plan urządzenia lasu uwzględnia zakres $\mathrm{PZO}^{19}$ ). Plan zadań ochronnych sporządzany jest na podstawie istniejącej wiedzy uzupełnionej o określone podstawowe prace terenowe w standardzie „obserwacji monitoringowej” ${ }^{20}$ - w celu zestandaryzowanego opisania stanu ochrony poszczególnych przedmiotów ochrony. Dopuszcza się także ewentualną weryfikację lub rozpoznanie uwarunkowań realizacji planowanych zadań. W tym zakresie taka weryfikacja może także uwzględniać modyfikację celów zrównoważonego rozwoju lub też wprowadzenie jego nowej definicji. Należy jednak zauważyć, że zmiana planu zadań ochronnych wymaga takiej samej skomplikowanej procedury co jego wydawania, co niewątpliwie może spowolnić proces realizacji nowych celów zrównoważonego rozwoju.

Analizując relacje planów działalności rolnośrodowiskowych oraz planów zadań ochronnych oraz etapy i procedury ich powstawania należy postulować rozważenie doprowadzenia do spójności w głównych możliwych elementach planów działalności rolnośrodowiskowej oraz planów zadań ochronnych. Wydaje się, że racjonalnym rozwiązaniem będzie przyznanie pierwszeństwa postanowieniom planu zadań ochronnych oraz uzupełniającego charakteru planów działalności rolnośrodowiskowych. W praktyce mogłoby się to sprowadzać do stosownego zapisu umownego zobowiązującego beneficjenta działania rolnośrodowiskowego do przestrzegania postanowień planu zadań ochronnych oraz dodatkowych (niewykluczających się) możliwych wymagań planu działalności rolnośrodowiskowej. Plan zadań ochronnych mógłby być częścią planu działalności rolnośrodowiskowej. Taka zmiana z pewnością uprościłaby rozwiązanie konfliktów wynikających z realizacji obu planów.

W opisanym powyżej zakresie konfliktu zachodzi wiele wątpliwości prawnych oraz faktycznych. Dotyczy to przede wszystkim sytuacji, kiedy na ten sam podmiot nakłada się te same obowiązki z dwóch różnych podstaw prawnych. Przykładowo obowiązek odpowiedniego nawożenia pola może wynikać zarówno z prawa publicznego - w tym przypadku z planów zadań ochronnych, ale także z prawa prywatnego - zobowiązań rolnośrodowiskowych. Należy podkreślić, że takie sytuacje nie są w praktyce rzadkie. Realizując szczegółowo ideę zrównoważonego rozwoju obszarów wiejskich na obszarach objętych Naturą 2000 nie wolno zapominać, że na tych samych obszarach może być już prowadzona działalność rolnicza. Powstaje pytanie, którym obowiązkom dać pierwszeństwo, które są ważniejsze? Ta klasyczna kolizja pomiędzy prawem publicznym a prywatnym wskazuje na pilną koniecz-

D. Strus (red.), Warszawa 2012, s. 117-124; J. Boć, K. Nowacki, E. Samborska-Boć, Ochrona środowiska, KoIonia 2002; P. Bojarski, Rekompensata..., op. cit.; W. Bołdok, Kilka uwag..., op. cit.; K. Gruszecki, Następstwa prawne..., op. cit.; L. Jastrzębski, Prawne zagadnienia ochrony przyrody, Warszawa 1980. w świetle art. 32 ust. 2 pkt 1 ustawy z 16 kwietnia 2004 r. o ochronie przyrody, Warszawa 2012, s. 5. 
ność zmian w tym zakresie. Nowelizacje i przede wszystkim nowy Program Rozwoju Obszarów Wiejskich powinien nie tylko uwzględniać tego typu aspekty, ale także należy wziąć pod uwagę nowe rozwiązania dotyczące zrównoważonego rozwoju. W tym zakresie należy uwzględnić w szerszym względzie istniejące plany zadań ochronnych, które mogą być wykorzystywane przy ubieganiu się o pomoc z poszczególnych działań rolnośrodowiskowych. Przyszły PROW powinien być w dużo większym stopniu powiązany z istniejącymi regulacjami dotyczącymi sieci Natura 2000 i w większym stopniu wykorzystywać dostępne akty prawa powszechnie obowiązującego. Spełnienie tego postulatu usprawni przyznawanie pomocy rolnikom, ale także doprowadzi do obowiązywania kompleksowych i komplementarnych regulacji, które nie będą stały ze sobą w sprzeczności. Niewątpliwe również sprzyjać to będzie realizacji idei zrównoważonego rozwoju na obszarach wiejskich. ${ }^{21}$

Należy także wziąć pod uwagę możliwe problemy czasowe związane z procesem legislacyjnym oraz przyjętym na szczycie Rio+20 harmonogramem. Nowy PROW obejmujący lata 2014-2020 będzie musiał prawdopodobnie powstać do końca 2013 r. Obecnie trwa kolejny etap konsultacji społecznych w tym zakresie. ${ }^{22}$ W tym samym czasie powołana na szczycie grupa robocza ma ustalić nowe cele zrównoważonego rozwoju, które dopiero w 2015 r. mają zastąpić tzw. cele milenijne. Może się okazać, że nowy PROW będzie realizował dotychczasową politykę zrównoważonego rozwoju, nie uwzględniającą w wystarczający sposób celów Natury 2000 oraz ustaleń szczytu Rio+20. Wskazać także należy na dotychczasową ogólność stosowanych zaleceń w dokumencie końcowym szczytu. Niewątpliwie formuły w postaci klauzul generalnych są korzystne pod względem ich szerokiej interpretacji i osiągania międzynarodowego porozumienia, stanowić jednak mogą poważne zagrożenie dla skuteczności realizacji zakładanych celów. Już dziś przygotowując nowy PROW trzeba pamiętać, że być może zaistnieje potrzeba jego zmiany i redefiniowania celów zrównoważonego rozwoju, które w PROW występują zarówno jako samoistna definicja, jak też przez system odwołań np. do ustawy o ochronie przyrody. Tego typu sytuacja niepewności prawa może sprzyjać zmianom reguł uzyskiwania pomocy $w$ trakcie danego naboru lub też w trakcie jego realizacji. W tym zakresie należy jednoznacznie określić, zarówno $\mathrm{w}$ decyzjach administracyjnych, jak też i w umowach z beneficjentami pomocy zakres rozumienia idei zrównoważonego rozwoju dla poszczególnych działań.

Kolejnym problemem z zakresu konfliktu pomiędzy regulacjami publicznooraz prywatnoprawnymi jest sposób i zakres oddziaływania wprowadzenia obsza-

M.A. Król, Obszary o wysokich wartościach przyrodniczych i ich znaczenie w ochronie różnorodności biologicznej na obszarach wiejskich, [w:] Administracja publiczna a ochrona przyrody. Zagadnienia ekonomiczne, społeczne oraz prawne, M. Górski, D. Niedziółka, R. Stec, D. Strus (red.), Warszawa 2012, s. 47-66. http://www.minrol.gov.pl/pol/Wsparcie-rolnictwa-i-rybolowstwa/PROW-2014-2020, dostęp na 15.08.2013. 
rów Natura 2000 na danym terytorium. ${ }^{23}$ Proces ustanowienia na danym terenie obszaru Natura 2000 powoduje konieczność zmiany sposobu użytkowania obszarem, którego dotyczy zmiana. ${ }^{24}$ Wprowadzenie na danym terenie nowej formy ochrony przyrody, jaką jest Natura 2000, nie powoduje ograniczenia działalności gospodarczej, leśnej, łowieckiej i rybackiej, jeżeli taka działalność nie oddziałuje znacząco negatywnie na cele ochrony obszaru Natura $2000 .{ }^{25} \mathrm{~W}$ tym zakresie rozwój działalności gospodarczej jest ograniczany jedynie poprzez zakaz negatywnego oddziaływania na chroniony obszar. W przypadkach szczególnie uzasadnionych można zezwolić na prowadzenie działalności znacząco negatywnie oddziałującej na cele ochrony obszaru Natura 2000, zapewniając jednocześnie odpowiedni system kompensacji przyrodniczej. Konflikt pomiędzy publicznoprawnymi regulacjami wynikającymi z ustawy o ochronie przyrody a prywatnoprawnymi postanowieniami ustawy o swobodzie działalności gospodarczej ${ }^{26}$ musi w tym zakresie zostać rozwiązany poprzez z jednej strony system kompensacji przyrodniczej, z drugiej specjalny system odszkodowań dla podmiotów gospodarczych, których działalność została ograniczona poprzez ustanowienie obszaru Natura 2000. Idea zrównoważonego rozwoju próbując pogodzić interes publiczny, jakim jest ochrona środowiska naturalnego i interes prywatny w postaci swobody działalności gospodarczej zakłada współistnienie chronionego środowiska oraz prowadzonej działalności gospodarczej. Efekty szczytu Rio+20 w tym zakresie mogą tylko umocnić tę pozytywną koegzystencję poprzez wspomnianą już promocję biznesu odpowiedzialnego społecznie. W zrównoważonym rozwoju powinno być zawarte rozwiązanie, które pogodziłoby konieczność ochrony środowiska, w szczególności na obszarach Natura 2000, a także prowadzenie określonej działalności gospodarczej na tych terenach.

Doprowadzenie do braku konfliktu w zakresie ustawy o ochronie przyrody i ustawie o swobodzie działalności gospodarczej napotyka jednak przeszkody. Po-

Por. także bardzo ciekawe rozważania A. Lipiński, Prawo własności a niektóre problemy obszarów Natura 2000, [w:] Administracja publiczna a ochrona przyrody. Zagadnienia ekonomiczne, społeczne oraz prawne, M. Górski, D. Niedziółka, R. Stec, D. Strus (red.), Warszawa 2012, s. 139-152.

24 K. Sundseth, P. Creed, Natura 2000: ochrona różnorodności biologicznej Europy, Luksemburg 2009; S.C.F. de Piérola, Natura 2000 i społeczeństwo: instrumenty komunikacji społecznej w zarządzaniu Siecią Natura 2000, Warszawa 2009; P. Rutkowski, Natura 2000 w leśnictwie, Warszawa 2009; B. Rakoczy, Ograniczenie praw i wolności jednostki ze względu na ochronę środowiska w Konstytucji Rzeczypospolitej Polskiej, Toruń 2009; B. Rakoczy, Komentarz do ustawy o zapobieganiu szkodom w środowisku i ich naprawie, Warszawa 2008; B. Wierzbowski, B. Rakoczy, Podstawy prawa ochrony środowiska, Warszawa 2007.

25 A. Kozińska, Administracyjna odpowiedzialność za działania, mogące znacząco negatywnie oddziaływać na cele ochrony obszaru Natura 2000, spełniające kryteria szkody w środowisku - stan obecny oraz propozycje nowych rozwiązań prawnych, [w:] Administracja publiczna a ochrona przyrody. Zagadnienia ekonomiczne, społeczne oraz prawne, M. Górski, D. Niedziółka, R. Stec, D. Strus (red.), Warszawa 2012, s. 321-330; K. Sobieraj, Stosowanie przesłanek zezwalających na realizację przedsięwzięcia mogącego znacząco oddziaływać na obszary Natura 2000 na przykładzie inwestycji w sektorze energetycznym, [w:] Administracja publiczna a ochrona przyrody. Zagadnienia ekonomiczne, społeczne oraz prawne, M. Górski, D. Niedziółka, R. Stec, D. Strus (red.), Warszawa 2012, s. 243-254; E. Czech, M. Kropiewnicka, Przegląd stanowisk judykatury w zakresie funkcjonowania decyzji środowiskowych na obszarach Natura 2000, [w:] Administracja publiczna a ochrona przyrody. Zagadnienia ekonomiczne, społeczne oraz prawne, M. Górski, D. Niedziółka, R. Stec, D. Strus (red.), Warszawa 2012, s. $257-268$. Ustawa z dnia 2 lipca 2004 r. o swobodzie działalności gospodarczej (Dz.U. z 2013 r. poz. 672 z późn. zm.). 
ważne problemy prawne powstają, kiedy prowadzonej działalności gospodarczej nie można pogodzić z zasadami obszaru chronionego. Wtedy idea zrównoważonego rozwoju nie jest realizowana. W tym sporze do tej pory zwycięża prawo publiczne stojące na straży ochrony środowiska. Prawo prywatne w tym zakresie ogranicza się jedynie do roszczeń odszkodowawczych. Przedstawione poniżej możliwości odszkodowawcze są dziś jedyną możliwością ochrony podmiotów prowadzących działalność gospodarczą na obszarach Natura 2000. Zdarza się też, że samo odszkodowanie nie rekompensuje braku możliwości zarobkowania. Sama ocena znacznego negatywnego oddziaływania na cele ochrony obszaru Natura 2000 wydaje się bliżej niedookreślona, pozostawiając zbyt wiele możliwości uznaniowości decyzji organów administracji publicznej. ${ }^{27}$

Ustanowienie obszaru Natura 2000 może wiązać się także ze zmniejszeniem wartości nieruchomości objętych obszarem lub zmniejszeniem dochodowości prowadzonej działalności na danym obszarze. Ustawodawca polski przewidział w tym zakresie dwie możliwe sytuacje.

Pierwsza z nich to możliwość żądania wykupienia nieruchomości lub jej części przewidziana w art. 129 ust. 1 ustawy z dnia 27 kwietnia 2001 r. - Prawo ochrony Środowiska, ${ }^{28}$ jeżeli w związku z ograniczeniem sposobu korzystania z nieruchomości lub z jej części w dotychczasowy sposób lub zgodny z dotychczasowym przeznaczeniem stało się niemożliwe. Uprawnienie do takiego żądania przysługuje właścicielowi nieruchomości oraz użytkownikowi wieczystemu. Ponadto te podmioty oraz osoba, której przysługuje prawo rzeczowe do nieruchomości (w doktrynie przyjęto, że są to także użytkownicy nieruchomości oraz osoby posiadające prawo dożywocia, zgodnie z art. $91 \mathrm{kc}$.) może żądać odszkodowania za poniesioną szkodę, w tym za zmniejszenie wartości nieruchomości. Wartość tego odszkodowania ustala w drodze decyzji starosta. Jak podkreśla się w orzecznictwie odszkodowanie nie jest ograniczone do rzeczywistej straty, obowiązuje bowiem zasada pełnej odpowiedzialności odszkodowawczej za wprowadzenie ograniczeń w korzystaniu z nieruchomości, opartej także na zasadach prawa cywilnego przewidzianych w art. 361 $\S 2$ kodeksu cywilnego. ${ }^{29}$ Budzi to jednak pewne wątpliwości, bo niejednokrotnie bardzo trudno jest wycenić dochodowość w przyszłości podmiotu gospodarczego. Należy pamiętać, że możliwość wystąpienia z oboma żądaniami jest ograniczona do 2 lat od dnia wejścia w życie rozporządzenia lub aktu prawa miejscowego powodującego ograniczenie sposobu korzystania z nieruchomości. Powstanie szkody należy jednak ocenić w momencie opublikowania aktu lub w krótkim okresie jego obowią-

27 D. Strus, Właściwość organów jednostek samorządu terytorialnego w tworzeniu i funkcjonowaniu niektórych form ochrony przyrody, [w:] Administracja publiczna a ochrona przyrody. Zagadnienia ekonomiczne, społeczne oraz prawne, M. Górski, D. Niedziółka, R. Stec, D. Strus (red.), Warszawa 2012, s. 165-174. 
zywania. ${ }^{30}$ Roszczenia odszkodowawcze $\mathrm{w}$ tym zakresie są rekompensatą nie tylko za poniesioną szkodę, ale także za zachwianie zrównoważonego rozwoju. W tym zakresie rozwój środowiska naturalnego oraz jego ochrona mają pierwszeństwo.

Drugą z możliwości rekompensat jest procedura umowna określona w art. 36 ust. 3 ustawy o ochronie przyrody. Przewiduje ona, że jeżeli w wyniku wprowadzenia na danym terenie sieci obszarów Natura 2000, prowadzona działalność gospodarcza, rolna, leśna, łowiecka lub rybacka wymaga dostosowania do wymogów ochrony obszaru Natura 2000, a na tym obszarze nie mają zastosowania programy wsparcia z tytułu obniżenia dochodowości, regionalny dyrektor ochrony środowiska może zawrzeć umowę $\mathrm{z}$ właścicielem lub posiadaczem obszaru. Umowa ta nie może być zawarta z zarządcą nieruchomości Skarbu Państwa. W umowie, zgodnie z ustawą, określa się:

1. wykaz niezbędnych działań, sposoby i terminy ich wykonania oraz warunki i terminy rozliczenia należności, za wykonane czynności oraz

2. wartość rekompensaty za utracone dochody wynikające z wprowadzonych ograniczeń.

Zawarcie umowy jest możliwe, jeżeli na danym obszarze nie miał zastosowania żaden z programów pomocowych z tytułu obniżenia dochodowości. Obecnie są to środki pochodzące z Europejskiego Funduszu Rolnego Rozwoju Obszarów Wiejskich, Europejskiego Funduszu Społecznego, Europejskiego Funduszu Rozwoju Regionalnego, Funduszu Spójności, Europejskiego Funduszu Rybactwa, Instrumentu Finansowego na rzecz Środowiska LIFE+, VII Programu Ramowego. Do takich programów pomocowych w Polsce można także zaliczyć projektowaną płatność dla obszarów Natura 2000.

W przypadku, gdy żaden z wymienionych środków pomocowych nie może mieć zastosowania, regionalny dyrektor ochrony środowiska może zawrzeć opisaną powyżej umowę. Umowa może być zawarta, z jednym wyjątkiem, z właścicielem lub posiadaczem nieruchomości. W umowie określa się przede wszystkim wysokość rekompensaty za utracone dochody wynikające z wprowadzonych ograniczeń, a także powyżej opisane niezbędne działania. Powstaje także pytanie, czy zawarcie takiej umowy jest tylko możliwością, czy też obowiązkiem, którego można ewentualnie dochodzić na drodze sądowej. Literalne brzmienie przepisu wskazuje na możliwość zawarcia umowy, jednakże stosując wykładnię funkcjonalną i konstytucyjną zasadę ochrony własności należy uznać, że zawarcie powyżej opisanej umowy, którą przewiduje ustawa o ochronie przyrody, jest obowiązkiem regionalnego dyrektora ochrony środowiska. 
Podkreślić także należy, że obecna regulacja nie przewiduje takich sytuacji, jak rekompensaty dla osób zamierzających prowadzić opisaną działalność na obszarze Natura 2000 (mających np. swoje nieruchomości w bezpośrednim sąsiedztwie obszaru Natura 2000). Takie rozwiązanie prawne mogłoby się znaleźć w ustawie o ochronie przyrody, z zastrzeżeniem, że taki podmiot wykazałby w sposób niebudzący zastrzeżeń swoją szkodę powstałą w wyniku wprowadzanych ograniczeń. Byłoby ono uzupełnieniem nowej idei zrównoważonego rozwoju i odpowiadałoby postulatom prezentowanym podczas szczytu Rio+20.

W obecnym polskim systemie prawa brakuje też regulacji, w których właściciele nieruchomości bezpośrednio sąsiadujących z obszarem Natura 2000 mogliby się ubiegać o odszkodowanie z tytułu ewentualnego obniżenia wartości ich nieruchomości. Oni również na swoich nieruchomościach muszą realizować ideę zrównoważonego rozwoju. Niestety, brak możliwości ubiegania się o ewentualne rekompensaty w obecnym systemie prawnym jest niemożliwy. Wskazać należy, że pomimo, iż ich tereny nie są objęte bezpośrednio formą ochrony przyrody - Natura 2000, to jej wprowadzenie oddziałuje również na prowadzoną przez nich działalność gospodarczą. Wprowadzając zmiany do ustawy o ochronie przyrody można rozważyć wskazanie również na możliwość stosownych rekompensat dla tej grupy właścicieli, którzy bezpośrednio sąsiadują z obszarami Natura 2000.

Kolejną kwestią, która nie jest jasno uregulowana, pozostaje też sprawa rekompensat dla gmin, na obszarach których ustanawia się sieć Natura 2000. Przy ewentualnych zmianach omawianych regulacji rekomenduje się rozważenie ich wprowadzenia, uwzględniając nowe cele zrównoważonego rozwoju.

Przedstawione problemy sprowadzają sie do kilku zasadniczych kwestii.

Po pierwsze relacji pomiędzy zrównoważonym rozwojem obszarów wiejskich realizowanym w ramach PROW a ochroną środowiska naturalnego w ramach Natury 2000, realizowanej poprzez ustawę o ochronie przyrody. Regulacje w tym zakresie powinny się uzupełniać, a nie powielać lub wykluczać. De lege ferenda należy postulować tutaj zmiany, w szczególności polegające na nowej koncepcji PROW, uwzględniającej także efekty szczytu Rio+20. Zrównoważony rozwój realizowany w ramach PROW powinien realizować tożsame cele, które zakładane są przy tworzeniu obszarów Natura 2000. Ustanowienie hierarchii norm regulujących sieć obszarów Natura 2000 oraz PROW, na rzecz wskazania prymatu rozwiązań zawartych $\mathrm{w}$ ustawie o ochronie przyrody powinno być sprawą zasadniczą. PROW w tym zakresie powinien jedynie wtedy wskazywać na realizację celów ochrony obszarów Natura 2000, kiedy nie istnieje rozwiązanie prawne w ustawie lub też aktach prawa powszechnie obowiązującego wydanych na podstawie ustawy.

Po drugie istnieje wyraźny konflikt pomiędzy regulacjami publicznoprawnym oraz prywatnoprawnymi w zakresie rozwiązań szczegółowych dotyczących Natury 
2000, w tym koncepcji zrównoważonego gospodarowania. Podane przykłady relacji planów zadań ochronnych z innymi aktami prawnymi oraz problematyki odszkodowawczej to tylko jedno $\mathrm{z}$ licznych oblicz tego konfliktu. Istniejące rozbieżności należy usunąć i w miarę możliwości wyeliminować z obiegu prawnego. W szczególności pilnego uregulowania wymagają relacje planów zadań ochronnych i zobowiązań rolnośrodowiskowych. W tym zakresie ponownie należy podkreślić, że plan zadań ochronnych, $\mathrm{z}$ uwagi na procedurę tworzenia oraz rangę $\mathrm{w}$ hierarchii źródeł prawa powinien mieć charakter podstawowy.

Po trzecie pojawia się problem niejasności przepisów i zasad dotyczących zrównoważonego rozwoju i jego właściwego recypowania do poszczególnych aktów prawa krajowego. W tym zakresie należy życzyć sobie jak najszybszego i jak najlepszego zakończenia obrad zespołu roboczego, który wypracowuje nowe cele zrównoważonego rozwoju po szczycie Rio+20. Ich właściwe zrozumienie i przełożenie na konkretne rozwiązania prawne będzie miarą powodzenia tego szczytu. W przypadki ich braku lub negatywnych wyników w procesie stosowania prawa idea zrównoważonego rozwoju może nie zostać w pełni zrealizowana. 
EUROPEAN ECOLOGICAL NETWORK NATURA 2000 AND THE SUSTAINABLE DEVELOPMENT OF RURAL AREAS

Key words: Natura 2000, Rio+20, sustainable framework for rural areas, conservations plans.

The article presents the legal issues related to the concept of sustainable framework for rural areas of the European Ecological Network Natura 2000. The article presents the effects of Rio+20 summit and their impact on European and national conservation regulations, in particular the Natura 2000 sites. The article also identifies possible risks associated with the implementation of new aims at sustainability, which were decided in Rio+20. In conclusion author pointed to possible solutions de lege ferenda and the most important legal issues related to the relationship of the Natura 2000 sites and to sustainable development. It was pointed out problematic aspects of conservations plans and their relationship with other legislation. The article discussed also the issue of compensation for the reduction in value of property which are located on area of Natura 2000 or reduce the profitability of the business on a Natura 2000 site. 